\title{
Evidence for a Long-Distance Trade in Bois D'Arc Bows in 16th Century Texas (Maclura Pomifera, Moraceae)
}

Leslie L. Bush

Macrobotanical Analysis

Follow this and additional works at: https://scholarworks.sfasu.edu/ita

Part of the American Material Culture Commons, Archaeological Anthropology Commons, Environmental Studies Commons, Other American Studies Commons, Other Arts and Humanities Commons, Other History of Art, Architecture, and Archaeology Commons, and the United States History Commons

Tell us how this article helped you.

This Article is brought to you for free and open access by the Center for Regional Heritage Research at SFA ScholarWorks. It has been accepted for inclusion in Index of Texas Archaeology: Open Access Gray Literature from the Lone Star State by an authorized editor of SFA ScholarWorks. For more information, please contact cdsscholarworks@sfasu.edu. 


\section{Evidence for a Long-Distance Trade in Bois D'Arc Bows in 16th Century Texas (Maclura Pomifera, Moraceae)}

\section{Licensing Statement}

Reproduction, posting, transmission, or other distribution or use of the Journal volume, individual article or any portion of the material therein, in any medium, is permitted strictly for personal, non-commercial purposes via a personal-use exemption under a Creative Commons license granted by JTAH.org, Inc. This license exemption requires, as a condition of its granted permission, proper credit be attributed to JTAH.org as copyright holder (e.g., Journal of Texas Archeology and History.org @ 2014). No part of this publication may be reproduced, posted, transmitted, or otherwise utilized or distributed in any form by any means or method for commercial purposes without the express written consent of the Publisher. Inquiries should be addressed to JTAH Publisher, Suite 307, Box 361, 5114 Balcones Woods Drive, Austin, Texas, 78759.

The Journal of Texas Archeology and History.org is an organization dedicated to furthering research, education and public outreach in the fields of archeology and history concerning Texas and its bordering states of Louisiana, Arkansas, Oklahoma, New Mexico and Northern Mexico; a region we call the "Texas Borderlands." The J.T.A.H. is collaborating with the Index of Texas Archaeology and S.F.A.S.U. to distribute their publication library to the general public via free and open-access channels. Visit www.JTAH.org to submit an article. 


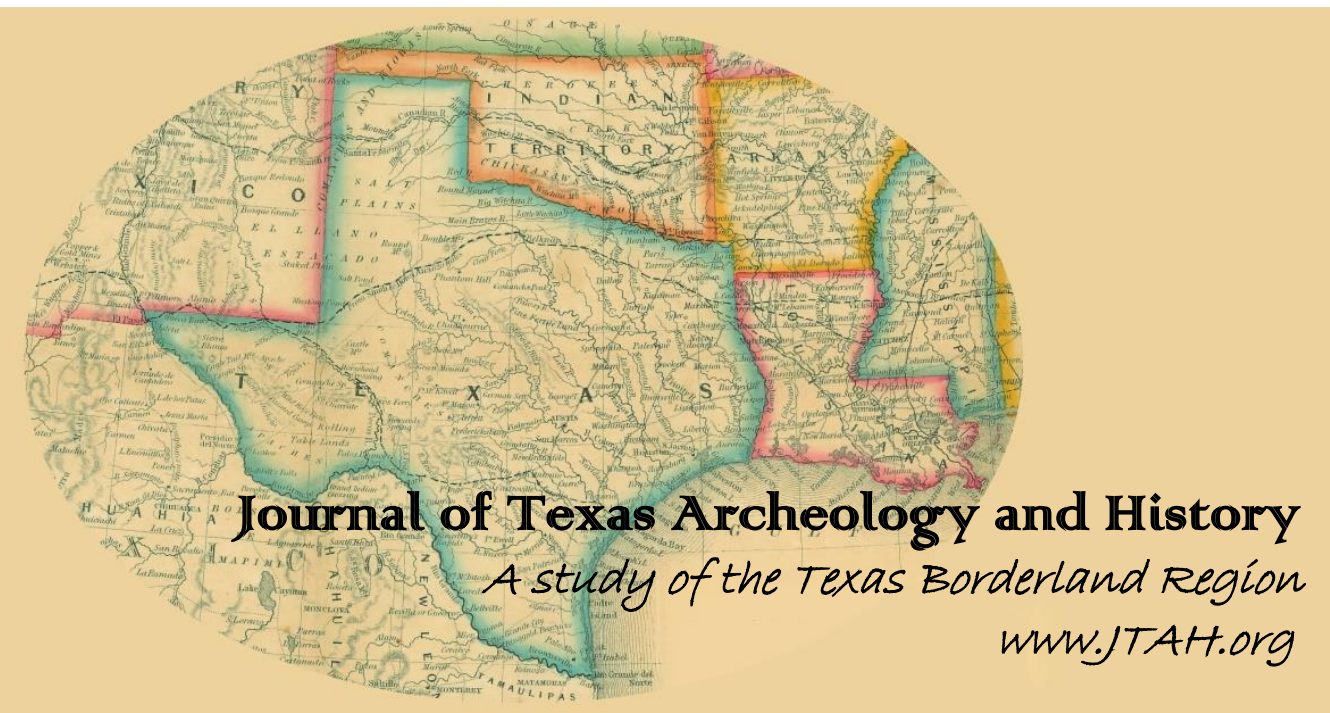

\section{Article Title: EVIDENCE FOR A LONG-DISTANCE TRADE IN BOIS D'ARC BOWS IN 16TH CENTURY TEXAS (MACLURA POMIFERA, MORACEAE)}

\section{Author(s): $\quad$ Leslie L. Bush}

Original Source: J.T.A.H. Volume 1 (2014), Article 3, pp. 51 - 69; online 20 November 2014

Recommended Citation: Bush, Leslie L., "Evidence for a Long-Distance Trade in Bois d'Arc Bows in $16^{\text {th }}$ Century Texas (Maclura Pomifera, Moraceae)", (2014), Journal of Texas Archeology and History Volume 1 (2014), pp. 51-69.

Copyright $@ 2014$ by Journal of Texas Archeology and History.org, Inc. All rights reserved. Online/Digital publication: ISSN 2334-1874

The online, digital and print versions of the publication "Journal of Texas Archeology and History" are published by Journal of Texas Archeology and History.org, Inc., a Texas nonprofit IRC Section 501(c)(3) corporation.

Reproduction, posting, transmission, or other distribution or use of the Journal volume, individual article or any portion of the material therein, in any medium, is permitted strictly for personal, non-commercial purposes via a personal-use exemption under a Creative Commons license granted by JTAH.org, Inc. This license exemption requires, as a condition of its granted permission, proper credit be attributed to JTAH.org as copyright holder (e.g., Journal of Texas Archeology and History.org (C) 2014). No part of this publication may be reproduced, posted, transmitted, or otherwise utilized or distributed in any form by any means or method for commercial purposes without the express written consent of the Publisher. Inquiries should be addressed to JTAH Publisher, Suite 307, Box 361, 5114 Balcones Woods Drive, Austin, Texas, 78759.

The Journal of Texas Archeology and History.org is an organization dedicated to furthering research, education and public outreach in the fields of archeology and history concerning Texas and its bordering states of Louisiana, Arkansas, Oklahoma, New Mexico and Northern Mexico; a region we call the "Texas Borderlands." The J.T.A.H. is collaborating with the Index of Texas Archaeology and S.F.A.S.U. to distribute their publication library to the general public via free and open-access channels. Visit www.JTAH.org to submit an article. 


\title{
EVIDENCE FOR A LONG-DISTANCE TRADE IN BOIS D'ARC BOWS IN $16^{\mathrm{TH}}$ CENTURY TEXAS (MACLURA POMIFERA, MORACEAE)
}

\author{
Leslie L. Bush
}

\begin{abstract}
A piece of wood charcoal identified as bois d'arc (Maclura pomifera) was recovered from the Janee site $(41 \mathrm{MN} 33)$ in Menard County, Texas. The specimen has been directly dated to $400 \pm 30$ B.P., a period when no naturally-occurring bois d'arc stands are believed to have been present within 400 miles of the site. Bois d'arc ecology, economic uses of bois d'arc wood, and historical accounts of bois d'arc trade indicate the specimen is best interpreted as part of a trade item related to Caddo bow-making traditions in Northeast Texas and adjacent areas of other states.
\end{abstract}

\section{INTRODUCTION}

A single fragment of bois d'arc wood charcoal was recovered from Feature 2-B at the Janee site (41MN33) on the Edwards Plateau of Central Texas (Figure 1). A direct date on the specimen produced a measured radiocarbon age of $400 \pm 30$ B.P. with a $13 \mathrm{C} / 12 \mathrm{C}$ ratio of $-25.1 \%$, resulting in a conventional radiocarbon age of $400 \pm 30$ B.P. and 2 sigma calibrated age ranges of A.D. 1440 to 1520 and A.D. 1590 to 1620 (Beta-305763). The Janee site lies on terrace 3-4 m above the San Saba River near Menard, Texas, far outside what is typically cited as the range of bois d'arc trees during that period. The feature in which the bois d'arc was found belongs to a thick $(25 \mathrm{~cm})$ buried Toyah phase component with well-defined activity areas (Arnn 2007:393). The feature represents the remnant of a large burned rock feature, most of which was destroyed in the backhoe trench (BHT 5) that revealed the cultural deposits (Arnn 2007:396). The site is interpreted as a "broad spectrum hunter-gatherer residential base" (Arnn 2007:403). This article discusses the probable origin and use of the bois d'arc specimen in light of the evolutionary ecology of bois d'arc and historic accounts of its use and trade in the North American midcontinent.

\section{BIOLOGY AND ECOLOGY OF BOIS D'ARC}

The tree known botanically as Maclura pomifera has many common names, including bois d'arc, bodark, bowwood, Osage-orange, yellowwood, hedge-apple, horse-apple, monkey balls, and Indiana brains. It is a small deciduous tree with wind-pollinated male and female flowers produced on separate individuals, which can be completely separate trees or separate stems within a single stand of

\footnotetext{
JOURNAL OF TEXAS ARCHEOLOGY AND HISTORY

VOLUME 1:51-69

THE ONLINE PUBLICATION JOURNAL OF TEXAS ARCHEOLOGY AND HISTORY (ISSN 2334-1874)

IS PUBLISHED BY JOURNAL OF TEXAS ARCHEOLOGY AND HISTORY.ORG. COPYRIGHT (C) 2014 JOURNAL OF TEXAS ARCHEOLOGY AND HISTORY.ORG. ALL RIGHTS RESERVED.
} 

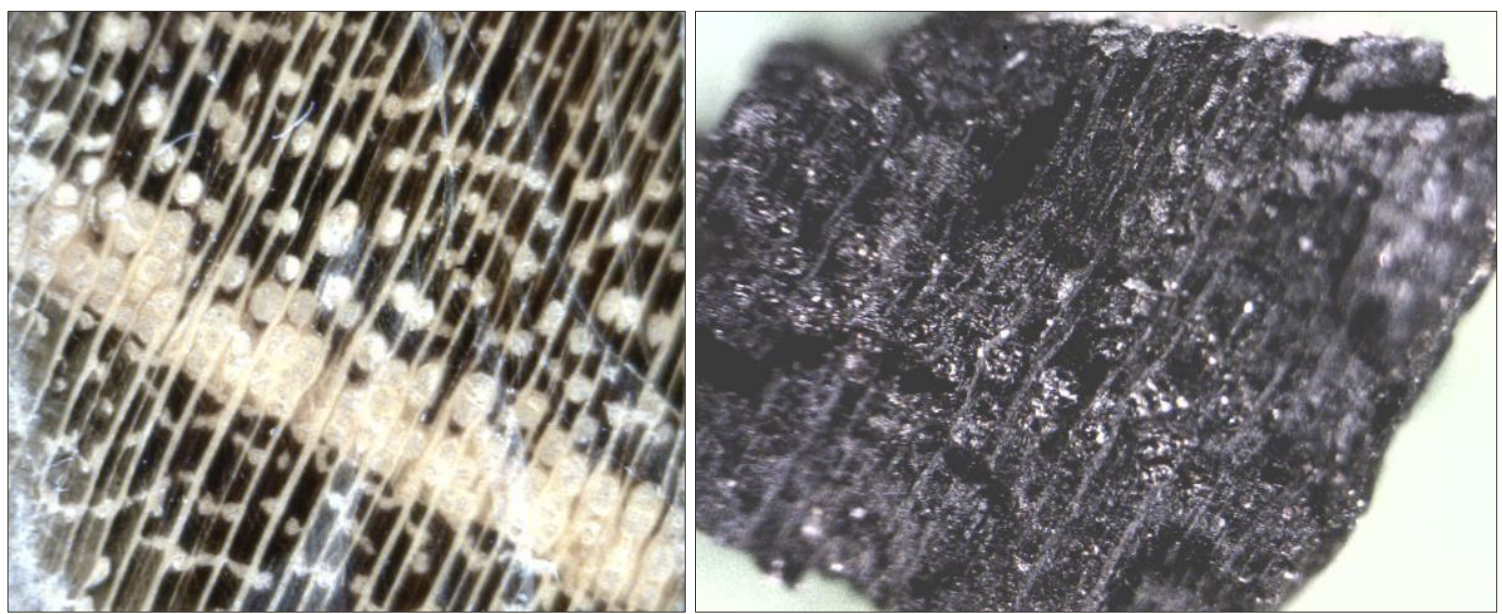

Figure 1. Modern bois d'arc wood (Maclura pomifera) (left) and Sample C-2 wood charcoal from the Janee site (right) in transverse section. Bands of earlywood (medium-large pores filled with tyloses) run from upper left to lower right across each image. Rays run orthogonally, from upper right to lower left. Photographed at $58 \mathrm{X}$.

trees (Bonner 2008) (Figure 2). Bois d'arc fruits are large (8-15 cm diameter) syncarps, aggregate fruits composed of single-seeded drupelets (Figure 3). Each fruit can thus have several male and female seeds, making it possible for a single fruit to generate a fertile stand of trees (Burton 1990; Carey 1994; Coder 1999; Smith and Perino 1981; Starr et al. 2003). Sterile fruits are also possible, however, when a female tree is not fertilized. The coarse fruits contain latex, which renders them unpleasantly sticky to most people. Bois d'arc fruits require contact with bare soil for germination and sunlight. The growing plants require direct sunlight, and sources agree that even mature bois d'arc is shade intolerant (Carey 1994; Smith and Perino 1981). Hence, it is not a tree of climax forests (Burton 1990; Smith and Perino 1981:30) Bois d'arc prefers deep bottomland soils such as those associated with forest edges or stream channels, but its taproot helps it tolerate a wide variety of situations as long as the requirements for bare soil and light are met (Elias 1980:257). Bois d'arc branches typically have thorns, although thornless cultivars exist today (Coder 1999). The branches are often curved or crooked (Coder 1999; Smith and Perino 1981:28), but the tree sprouts after cutting (coppice growth), typically providing straight wood under those circumstances (Carey 1994; Coder 1999; Starr et al. 2003). Bois d'arc wood is dense, with a specific gravity of 0.81 at 12 percent moisture (Hoadley 1990:Table 5.1). The wood is deep orange in color and highly resistant to decay thanks to the antifungal agents in the wood (Hoadley 1990; Smith and Perino 1981:34). Bois d'arc wood has extremely high strength and toughness under bending pressure. At 261 kilojoules per cubic meter $\left(\mathrm{kJ} / \mathrm{m}^{3}\right)$, the work-to-maximum load value for bois d'arc is the highest of any wood for which the USDA Forest Service provides data (Table 1), making it particularly suitable for use in bow making (Hamilton 1982).

\section{BOIS D'ARC AS AN ECONOMIC PLANT}

Since its discovery by Euro-Americans in the early $19^{\text {th }}$ century, bois d'arc trees have been commonly used as hedge plants. Their tough, durable wood has been in demand for fence posts, railway ties, and wooden wheels (Smith and Perino 1981; Westbrook 1973). Bois d'arc wood and root bark make yellow dye (Smith and Perino 1981). The coarse, sticky fruits are not considered edible by 


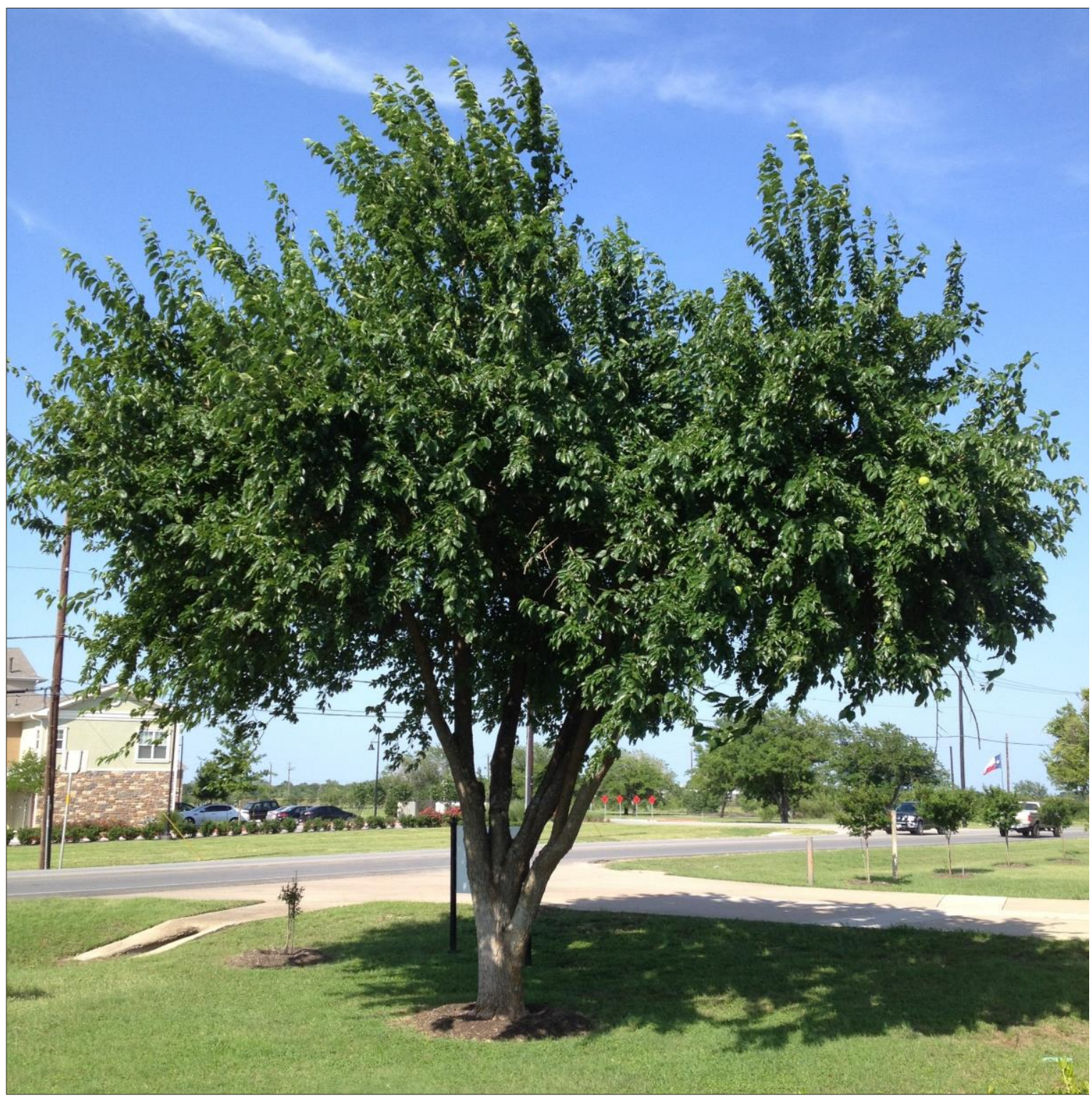

Figure 2. Bois d'arc tree (Maclura pomifera) near FM 1626 in Travis County, Texas. June 11, 2014.

humans, but they are not toxic to horses and cattle (Smith and Perino 1981:33-34). Proteolytic enzymes are found in the fruits, which makes them valuable in processes such as cheese-making and tenderizing meat that involve breaking down proteins into peptides or amino acids (Smith and Perino 1981:33). The fruits are widely considered to repel cockroaches (Ball 2000; Peattie 2007; Smith and Perino 1981; Turner 2009).

Bois d'arc's principal use among Native Americans gives the plant its common name. "Wood of the bow" was so named by the French explorers, soldiers, and trappers who were the first European inhabitants of the region where bois d'arc grew. Nineteenth century observers indicate that bois d'arc bows were highly prized on the American plains (Moerman 1998), and many authorities consider bois d'arc one of the two best bow woods in the world (Schambach 1995:11). In 1810, John Bradbury 


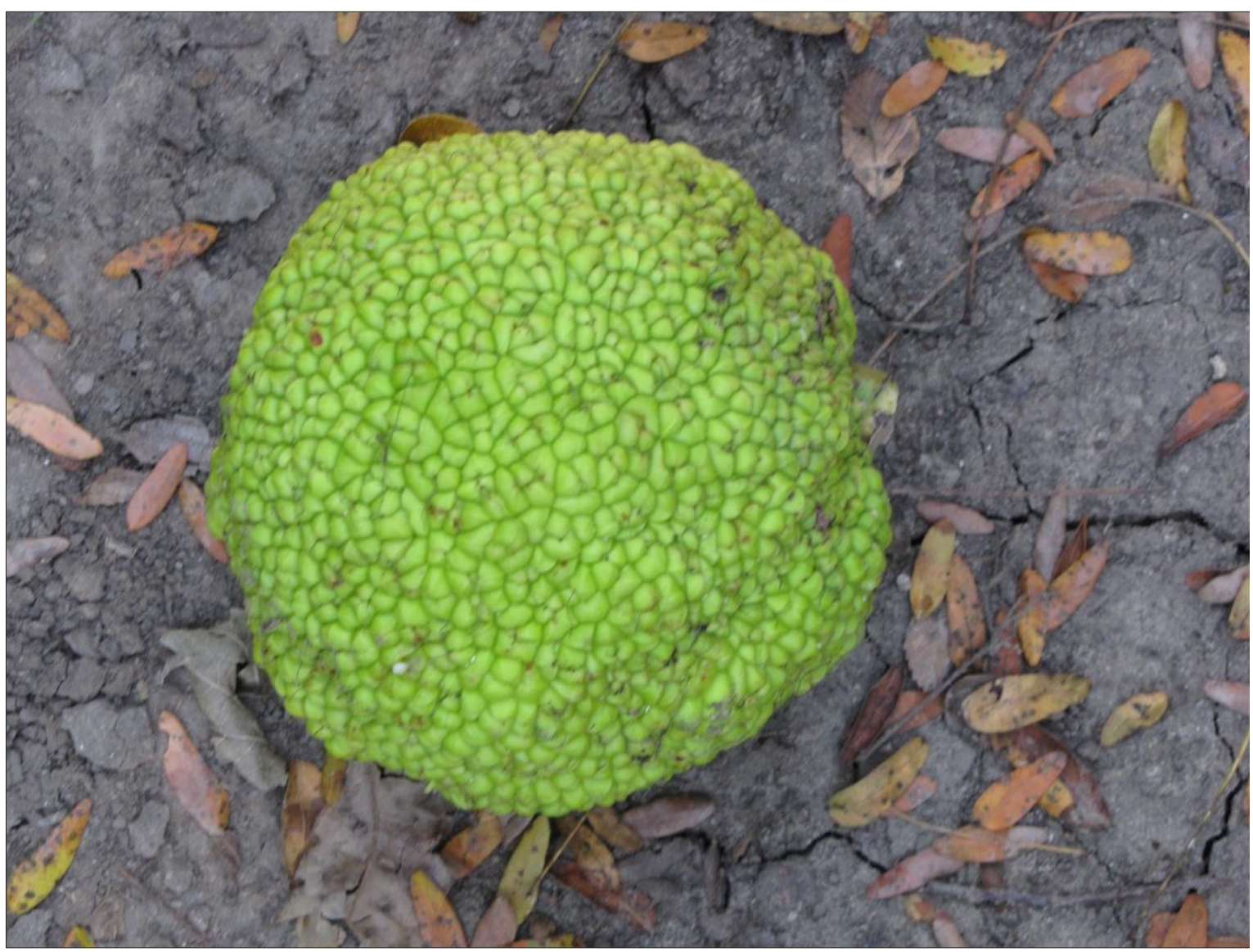

Figure 3. Bois d'arc fruit (Maclura pomifera) at Clear Creek Natural Heritage Center, Denton, Texas.

reported that the cost of a bow made from bois d'arc for Arikara Indians was a horse and a blanket. He described war clubs made of the same wood (Bradbury 1817:159-160). Prince Maximilian of Wied-Neuwied reported that Blackfeet Indians of Montana bartered for bois d'arc bows in the 1830s (Peattie 2007:387). On September 8, 1853, Lieutenant A. W. Whipple encountered a group of Kiowas on the Llano Estacado with outstanding bois d'arc bows (Whipple 1856:32). Archeological evidence indicates a long tradition of such use of the wood; an Early Caddo period (ca. A.D. 1000-1200) bow reportedly made from bois d'arc was excavated at the Mounds Plantation site (16CD12) in Caddo Parish, Louisiana (Webb and McKinney 1963, 1975). A few uses of bois d'arc for purposes other than bows are known among Native people. Kiowas and Pimas used the roots and wood for dye, and Comanches used a decoction of the root as an eyewash (Moerman 1998).

\section{BOIS D'ARC RANGE}

\section{Pre-Holocene}

Just as bois d'arc biology is unusual, so is its history, or at least what is known of its history. Ann Early (2000) pointed out more than a decade ago that much less is known about the evolutionary and geographical history of bois d'arc than is generally realized. Although recent progress has been made 
Table 1. Work to Maximum Load (WML) statistics for reputed bow woods and common woods of Central Texas (from Alden 1995).

\begin{tabular}{|c|c|c|c|}
\hline \multirow[b]{2}{*}{ Common name } & \multirow[b]{2}{*}{ Botanical name } & \multicolumn{2}{|c|}{ WML (kJ/m3) } \\
\hline & & Dry & Green \\
\hline Bois d'arc* & Maclura pomifera & no data & 261 \\
\hline Shagbark hickory* & Carya ovata & 178 & 163 \\
\hline Pacific yew* & Taxus brevifolia & 129 & 139 \\
\hline Cedar elm & Ulmus crassifolia & 128 & 138 \\
\hline Black locust* & Robinia pseudoacacia & 127 & 106 \\
\hline Pecan* & Carya illinoinensis & 95 & 101 \\
\hline Black walnut & Juglans nigra & 74 & 101 \\
\hline Hackberry & Celtis spp. & 88 & 100 \\
\hline Sugar maple & Acer saccharum & 114 & 92 \\
\hline Persimmon & Diospyros spp. & 106 & 90 \\
\hline Live oak & Quercus virginiana & 130 & 85 \\
\hline Green ash & Fraxinus pennsylvanica & 92 & 81 \\
\hline Madrone & Arbutus spp. & 61 & 77 \\
\hline Silver maple & Acer saccharinum & 57 & 76 \\
\hline Post oak & Quercus stellata & 91 & 76 \\
\hline Black willow & Salix nigra & 61 & 76 \\
\hline Holly/Yaupon & Ilex spp. & 74 & 74 \\
\hline Sumac & Rhus spp. & 58 & 74 \\
\hline Bigleaf maple & Acer macrophyllum & 54 & 60 \\
\hline Southern red oak & Quercus falcata & 65 & 55 \\
\hline Sycamore & Platanus occidentalis & 59 & 52 \\
\hline Cottonwood & Populus deltoides & 51 & 50 \\
\hline Mesquite & Prosopis spp. & no data & no data \\
\hline
\end{tabular}

*good bow wood, probably not present in Central Texas at the advent of bow technology.

in distinguishing pollen from different genera of the botanical family to which bois d'arc belongs (Moraceae) (Burn and Mayle 2008), pollen studies frequently include both Morus (mulberry) and Maclura in a single category (sometimes with the Urticaceae [nettle family] as well), rendering them less than useful for understanding the prehistoric range of Maclura. Researchers thus rely on the record of fossil woods, leaves, and fruits.

Widely-cited secondary sources indicate an extensive Pleistocene range for the genus Maclura in North America (e.g., Barlow 2000; Peattie 2007). Examination of the primary sources, however, reveals the wide range to be an extrapolation from a very few data points. Hugo Martínez-Cabrera and colleagues report fossil woods from early Miocene sediments in Baja California that may be ancestral to Maclura tinctoria, the species of Maclura found today in the Caribbean, Mexico, and Central and South America (Martínez-Cabrera et al. 2006). Theodore Delevoryas (1964:584) 
identifies "a multiple fruit, most closely allied to the Moraceae" from Upper Cretaceous deposits in South Dakota. Perhaps the most commonly cited finding for determining the Pleistocene range of bois d'arc is the presence of Maclura pomifera leaves and/or wood in the Don Beds in Ontario (Coleman 1933:9-10; Terasmae 1960; Woodcock 1989). The deposits date to the last interglacial period, $125,000-75,000$ years ago (Woodcock 1989). The Don Beds wood in general is characterized as decaying and much flattened by glaciers (Coleman 1933:9), but the leaves are not described, and the criteria for identification of individual wood and leaf taxa are not discussed. It appears that D. P. Penhallow, the botanist at McGill University who made the initial identifications, passed away prior to completion of the project (Coleman 1933:9). Two successor botanists are mentioned, Arthur Hollick and J. H. White, and they may have confirmed Penhallow's identifications. Fossil Maclura is known outside North America as well (Cheng et al. 2011).

\section{Pleistocene-Holocene Transition}

These spotty and imprecise records undergird the current theory that the genus Maclura had a wide distribution during the Pleistocene, with $M$. pomifera extending into what is now southern Canada and M. tinctoria (or its ancestor) present in Mexico. Daniel Janzen and Paul Martin (1982) have proposed that plants like bois d'arc were dispersed by Pleistocene megafauna. Although they mention bois d'arc only in passing, their theory has such explanatory power that it has been widely adopted for that species (Barlow 2000; Bonner 2008; Peattie 2007; Turner 2009). As North American populations of the dispersal organisms to which Maclura is adapted became reduced and eventually extinct (e.g., Pleistocene horses and camels), so Maclura's distribution shrank over the Holocene. As discussed below, historic records that explicitly refer to bois d'arc date to the early years of the $19^{\text {th }}$ century, by which time its range seems to have been restricted to a small area in Northeast Texas and adjacent parts of Arkansas and Oklahoma.

The Janzen-Martin hypothesis has the virtue of explaining several oddities about bois d'arc. The large fruits are poorly dispersed by the small animals that are attracted to them today (Smith and Perino 1981). The larger animals (i.e., bison) available to disperse large fruits during most of the Holocene apparently cannot consume bois d'arc fruits because they lack upper incisors (Barlow 2000). Although the tree can grow over a very wide swath of the North American continent under Holocene conditions, it apparently did not do so until it was planted extensively in the second half of the $19^{\text {th }}$ century. Even in conditions where bois d'arc has naturalized after an initial planting, reports of its continued reproductive success are mixed. Starr et al. (2003) argue that bois d'arc should be considered invasive in Hawai'i. They note bois d'arc is already prohibited as an invasive plant in Elburn, Illinois, and it has become a pest in Italy (Starr et al. 2003). Clearly, bois d'arc is a good pioneer species, but whether it is capable of persisting in a more mature landscape is unclear (Burton 1990; Coder 1999; Smith and Perino 1981). Bois d'arc stands were being shaded out by oaks in Hueston Woods State Park in Ohio as of 1981 (Smith and Perino 1981). 


\section{On the Possibility of Pleistocene Remnant Populations}

Several logical possibilities exist for the origin of the bois d'arc specimen at the Janee site. One is that it derives from Pleistocene refuge stands of bois d'arc that could, theoretically, have been present in West Texas during Toyah phase times. Anomalous stands of bois d'arc are known in Trans-Pecos Texas, for example in the Chisos Mountains and various locations around Marathon, Texas (Powell 1998:100-101; Roberts 2011; Simpson 1999:195; Turner et al. 2003; Wilson 1966:228). Some Chisos Mountain trees, notably Texas pinyon (Pinus remota), are believed to represent species that have managed to survive in small patches of microclimates to which they are well-suited (refugia) since Pleistocene times (Lanner and Van Devender 2000:173-174). The bois d'arc populations in West Texas do not have indicators of great antiquity in these locations, however. Botanists collecting the specimens have not indicated morphological differences between the West Texas and East Texas specimens that could be expected to have accumulated over a separation of 12 millennia. The Chisos Mountains specimens were collected in the 1930s and the identification re-checked by Dr. B. L. Turner in 2006 (TEX-LL 2007). To my knowledge, no archeological or geological specimens of Early or Middle Holocene-age bois d'arc have been recovered in Texas. Linguistic evidence also argues against great antiquity for these stands. The only Spanish name for bois d'arc I am aware of indicates an exotic origin for the plant: Naranjo Chino. Although its taproot makes bois d'arc relatively drought tolerant once established, even springs in West Texas may not provide enough moisture for long-term survival: of the 12 West Texas stands of bois d'arc known in the 1930s, only seven were alive in 2009 (Roberts 2011). Finally, bois d'arc populations are less numerous and contain fewer individuals than the more certain refugia populations of pinyon in West Texas (Thomas Alex, personal communication, September 6, 2011).

\section{On the Possibility of Holocene Native American Bois d'Arc Arboriculture}

Since the success of modern plantings indicate bois d'arc is capable of growing over a much larger range than it did in the early $19^{\text {th }}$ century, and Native Americans quickly adopted tree crops such as peaches (Gremillion 1993), the question of why Native Americans (apparently) did not plant this economically valuable tree deserves serious consideration. Frank Schambach, one of the few researchers who has approached the question, proposes a radically restricted range for bois d'arc trees-confined to Bois d'Arc Creek in Fannin County, Texas-that came under the control of a group that monopolized the resource for economic and political advantage during the Late Prehistoric (Schambach 1995). Although she comes to a slightly different conclusion about the Late Prehistoric range of bois d'arc trees, Ann Early also considers the possibility of Native American planting. She reviews historic accounts and General Land Office Records and concludes that bois d'arc range in the early historic period extended at least into the Little Missouri River valley if not the Arkansas River valley in Arkansas (Early 2000:108). She suggests that Caddo agricultural plots provided optimal

growing conditions for casually-introduced bois d'arc fruits (Early 2000:110). Deliberate establishment of bois d'arc stands would require a great deal of effort, and the deposition of a fertile fruit or viable cutting at exactly the right spot for optimum growth would likely provide only a fairly slim chance of a reward in bow wood 10-15 years in the future (Early 2000). 
The possibility of deliberately-introduced bois d'arc stands becomes correspondingly less probable in the less hospitable climate of West Texas. As noted above, small stands of bois d'arc currently exist in West Texas. Bois d'arc trees fruit for only about 75 years (Burton 1990; Coder 1999) and the oldest known trees are less than 200 years old (Smith and Perino 1981:28). Transplanted bois d'arc populations in West Texas must therefore have reproduced over several generations if they represent Late Prehistoric plantings. Many historically-known stands of bois d'arc died in the drought of the 1950s, suggesting the trees would not have survived through severe Late Prehistoric droughts such as those of the $12^{\text {th }}$ and $16^{\text {th }}$ centuries A.D. (Stahle et al. 2000; Woodhouse et al. 2010). (It should be noted, however, that the population at Bois D'Arc Springs in the Chisos Mountains, documented in 1937, survived the drought of the 1950s, and was still alive as of July 2011 [Thomas Alex, personal communication, September 6, 2011]). Perhaps more significantly, the wood from these bois d'arc stands, located far from their optimal habitat, is small and brittle, and thus ill-suited to bow-making (Thomas Alex, personal communication, September 6, 2011).

\section{7th Century}

The earliest historic reference to bois d'arc is believed to be that of Henri Joutel, who notes a bowmaking tradition in the Texas-Oklahoma-Arkansas-Louisiana area in 1687. He indicates that the wood is of excellent quality for bow-making ("du bois très proper à en faire [les arcs]"), that people travel great distances (50 or 60 leagues) to obtain the bows, and that the tree grows in quantity in the area (Margry 1879:412). Neither the wood nor the tree from which it came are named or described, however, either in the most recent English translation (Foster 1998:248) or in the French printed editions (DeMichel 1713:282; Margry 1879:412, 424). Joutel's omission is odd since he was reportedly the son of a gardener (Harisse 1872:165), and he took the trouble to describe a sweetgum tree that La Salle had marked near the Trinity River (Foster 1998:202, fn22) and palm trees near Garcitas Creek (Foster 1998:124). It seems likely that Joutel did not actually encounter a bois d'arc tree himself but only the bows or talk of bows. Ann Early (2000:102) points out it is possible that the entire bow-trading episode was inserted into Joutel's published account by the editors from Henry de Tonti's account of the expedition or a forged account falsely attributed to Tonti that circulated in Paris prior to 1713 (Delanglez 1985). To determine whether the episode was inserted into Joutel's account by an editor, a copy of the Joutel manuscript in the United States Library of Congress was examined but found to be inconclusive: the notebook covering the period of the Joutel's first mention of the bow trade (Cahier 14) was missing from the French National Marine archives at the time of transcription (Joutel 1684-1687) (Figure 4). A second reference to the bow trade is present, however, in the manuscript and in the Margry edition (Margry 1879:424). Although the notebook is missing, the first episode seems plausible given the second manuscript reference, the early $19^{\text {th }}$ century distribution of bois d'arc, the suitability of bois d'arc for bow making, and a probable history of bois d'arc bows in the area as evidenced by an Early Caddo bow reportedly made from bois d'arc recovered at Mounds Plantation in Caddo Parish, Louisiana (Webb and McKinney 1963, 1975). 


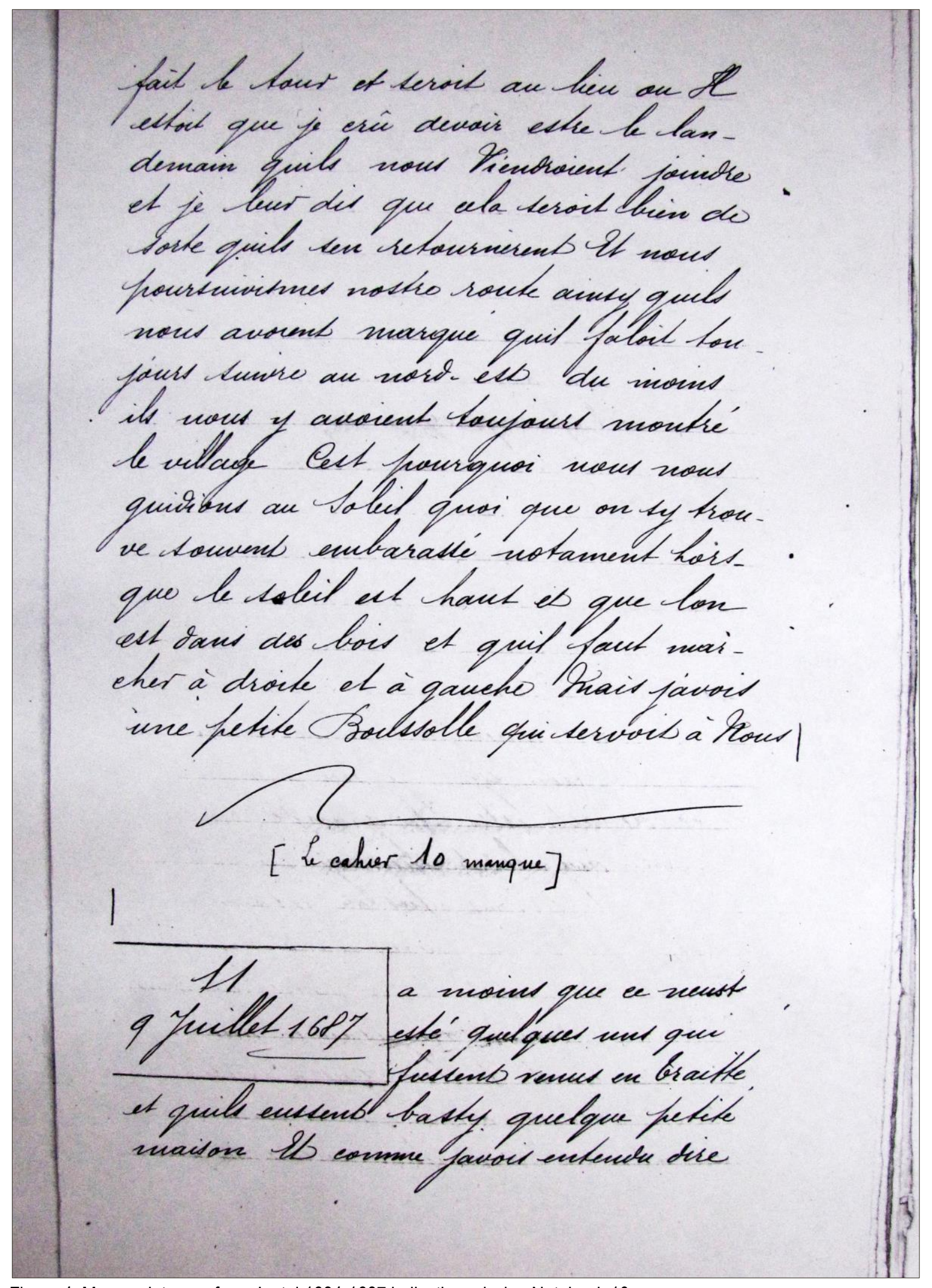

Figure 4. Manuscript page from Joutel 1684-1687 indicating missing Notebook 10. 


\section{8th Century}

Although there are few to no historic records of bois d'arc for the $18^{\text {th }}$ century, it is likely that bois d'arc expanded its range into West Texas during this time. Horses became common among Native American communities in Texas at the turn of the $18^{\text {th }}$ century, re-introducing a possible large mammal dispersal agent for bois d'arc populations. In his 1846 journal, Ferdinand Roemer indicates travelers progressed through Texas on horseback at about 40 miles per day (Roemer 2011:61). Horses

have a gut rate of about 24 hours (Town and Country Veterinary Hospital, personal communication, 2011). Bois d'arc stands reproduce after about 10 years (Smith and Perino 1981). Calculations from these data point to a maximum rate of advance for bois d'arc populations of about 40 miles per decade or four miles per year. In this scenario, the earliest bois d'arc could possibly become horse-dispersed in Menard is about 1804. Thus, the West Texas stands of bois d'arc could have become established prior to most European settlement but after the collapse of Toyah/Caddo trade networks.

\section{9th Century (Early)}

After 1803, historic references to bois d'arc become numerous. Meriwether Lewis famously sent bois d'arc samplings, which had been transplanted at an Osage village, to President Thomas Jefferson in 1804, with a note that their original source was 300 miles away, presumably on the Red River (Jurney 1995; Turner 2009). William Dunbar and George Hunter reported bois d'arc in the Ouachita River valley in 1804 (Early 2000:103; Jurney 1995). Peter Custis saw a very large specimen near Natchitoches in 1806 that may have been transplanted (Flores 1984:260). Anthony Glass described the first large wild stands in 1807 on the Red River, including the population on Bois D'Arc Creek that Schambach believes was the post-Pleistocene remnant population (Early 2000:106; Jurney 1995).

Smith and Perino (1981:Figure 2) noted that the extent of the "natural" range of bois d'arc was not known and provided four possible native distributions, all of which included Northeast Texas/Southwest Arkansas and two of which centered on that region. Later authors' examinations of documentary evidence have clarified the probable distribution of bois d'arc, at least as of 1860 in Texas.

Archeologist David Jurney (1995) and historian Del Weniger (1996) attempted to reconstruct the early historic and late prehistoric range of bois d'arc trees. Their efforts have focused on Texas, using historical accounts and General Land Office records prior to 1860 . Weniger restricts the range of bois d'arc to 12 counties in Northeast Texas (Figure 5). Jurney (1995) comes to very nearly the same conclusion but couches it in more satisfying ecological terms by naming the streams along which he believes the major populations of bois d'arc were dispersed: the East Fork of the Trinity River and one tributary, Rowlett Creek; the North Fork Sulphur River and some tributaries; and Bois D'Arc Creek, a tributary of the Red River in Fannin and Lamar counties, Texas. In the absence of Pleistocene megafauna, most authors believe water became the main dispersal agent of bois d'arc fruits (Barlow 2000; Jurney 1995). Weniger's and Jurney's findings may probably be extrapolated to areas immediately across the Red River in Oklahoma and Arkansas. 


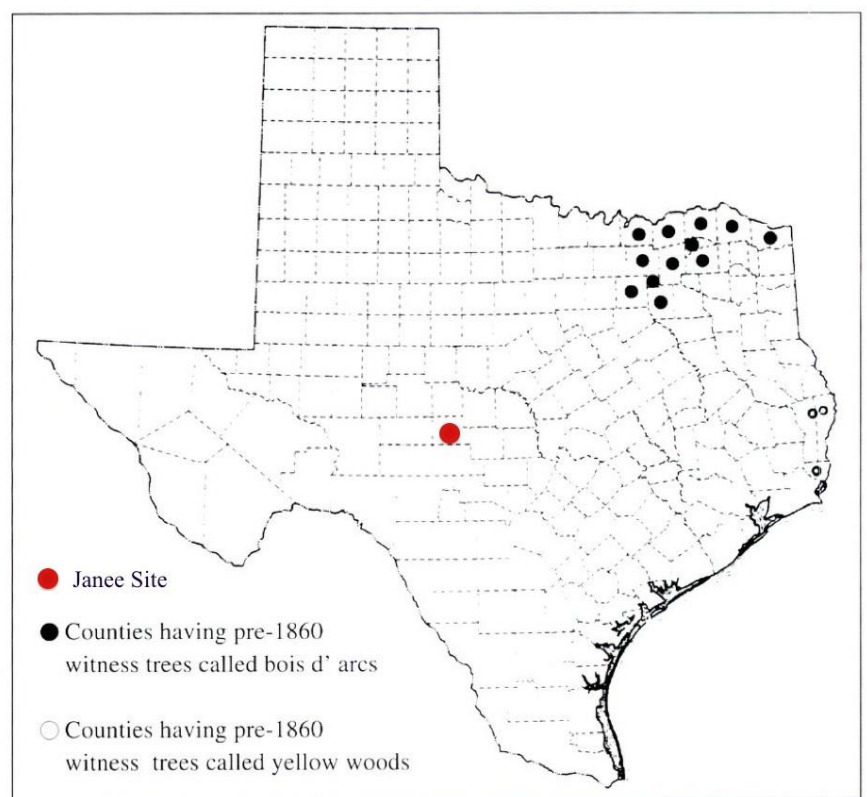

Figure 5. Pre-1860 range of bois d'arc (Maclura pomifera) indicated in solid black dots and the Janee site location in red. After Weniger (1996:Figure 2).

\section{9th Century (Late)}

The Prairie Farmer magazine was instrumental in greatly expanding the range of bois d'arc in the last half of the $19^{\text {th }}$ century, when it began to promote the tree as a hedge plant (Turner 2009). The first issue of Prairie Farmer in 1841 featured an editorial inquiry seeking information about such a use of bois d'arc. Over the next 14 years, bois d'arc discussions become increasingly commonplace in the journal, such that by 1855 another editorial attempted to settle the question of who should receive primary credit for introducing bois d'arc as a hedge plant. Bois d'arc place names can be found today throughout much of the United States, reflecting the success of the planting program. In fact, modern visitors to the Janee site usually travel Bois D'Arc Road to reach it.

\section{THE JANEE BOIS D'ARC SPECIMEN}

Identification of bois d'arc from fossil specimens, including archeological specimens, typically faces several difficulties, the most important of which is that identification is not usually made from the entire plant but from one or more parts of it. Maclura pomifera wood is ring-porous and packed with tyloses (Hoadley 1990; Panshin and deZeeuw 1980). It can be separated from mulberry (Morus spp.) and locust (Robinia pseudoacacia and $R$. neomexicana), which share these characteristics, by the presence of vestured intervessel pits (in Robinia) or crystals (in Maclura), or on the basis of ray seriation (the number of cells across the widest point in a ray). Mulberry wood has the widest rays, typically 7-8 seriate, while black locust rays are usually 3-5 seriate and bois d'arc's are 2-4 seriate (Hoadley 1990). The Maclura specimen at Janee was identified on the criterion of ray seriation: it has rays that are usually 2-3 seriate, with the largest rays being 4 seriate. It was not examined for the presence of vestured intervessel pits or crystals, but since the range of Robinia pseudoacacia, another good bow 
wood, is even more distant from the Janee site than bois d'arc, and $R$. neomexicana is also distant (250 miles, in the Guadalupe Mountains) and at 12-15 feet in height too small to provide good bow wood, examination of ray seriation is believed to be sufficient in this instance. Wood tissue of Maclura tinctoria, the Central American species, is diffuse-porous and easily distinguishable from Morus, Robinia, and Maclura pomifera in transverse section at low magnification.

Bois d'arc wood charcoal has been identified at post-A.D. 900 Caddo sites in East Texas, including Stallings Ranch (41LR297), Henry M. (41NA60), and Murphy Branch (41MX5) (Brewington et al. 1992; Bush 2008; Perttula et al. 2010). As discussed above, available evidence indicates the range of bois d'arc did not include Central Texas during the early $16^{\text {th }}$ century, when the Janee specimen was growing. The question of how and why bois d'arc wood arrived at the Janee site is thus more interesting than is usual for wood charcoal specimens on archeological sites.

Other woods identified at Janee are interpreted as fuel wood, both from their archeological contexts (hearths) and their taxa identifications. The six wood charcoal samples identified consisted of pecan, oak (red group, white group, and live group), mesquite, acacia, elm, and hoptree. These are all types of trees that would have grown along the San Saba River or in the uplands nearby, and which continue to grow in the area today. Both the transportation costs and properties of bois d'arc wood argue strongly against its use as a fuel wood at the Janee site. The transportation costs of using nonlocal wood for fuel are generally prohibitive (Asch and Asch 1986; Shackleton and Prins 1992), making the exotic bois d'arc an unlikely fuelwood. Further, although its wood is very dense, producing high heat and good coals, bois d'arc also produces so many sparks that it makes a distinctly unpleasant firewood (Graves 1919; Smith and Perino 1981:33). Given the probable range of bois d'arc in the early $16^{\text {th }}$ century and the wood's historically-documented uses among Native Americans, the Janee bois d'arc specimen was probably part of a bow or a stave for bow making.

Early historic trade routes between East Texas and La Junta (the confluence of the Rio Conchos and the Rio Grande) are documented through the Menard area, making it possible to identify the traders and the routes they traveled into Northeast Texas where the bows or their raw material would have been available. Arnn (2007:218, 420 and Figure 10.2) emphasizes the frequency and routine nature of travels by Jumanos between La Junta and Caddo villages in Northeast Texas. Exotic items other than bois d'arc were recovered from Janee in the form of arrow points (Arnn 2007:361), and exotic items are known from other Toyah phase sites in the area as well (Arnn 2007:359). Arnn proposes a continuity between the Late Prehistoric Toyah in this area and historic Jumano traders. Mariah Wade (2003:221, 248, note 44) notes that one sub-group of the Jumanos were known as the Good Bows (Arcos Buenos; also Arcos Fuertes or Arcos Tuertos or Los que Hacen Arcos). The "twisted" bows of this group are also referred to as "Turkish" bows; the term apparently describes a re-curved or double-curved bow. Double-curving does not necessarily make for a good bow (Hamilton 1982:6) but use of bois d'arc wood often does. Given the known location of large bois d'arc populations in Northeast Texas and the early historic evidence that Jumano traders with good bows traveled through the Janee site area, it seems likely that the bois d'arc fragment at Janee is best interpreted as part of a trade item from Northeast Texas, a bow or stave intended for bow-making. 


\section{ACKNOWLEDGEMENTS}

Many people generously shared ideas, expertise, and special knowledge of bois d'arc trees for this project. Special thanks are due to Jim Abbott, Tom Alex, John Arnn, Steve Black, Steve Carpenter, Ann Early, Claude Hudspeth, Jocelyne LeBrun, Chris Lintz, Scott Pletka, David Riskind, Tim Roberts, Travis Roberts, Lewis Wyman, the Town and Country Veterinary Hospital, and an anonymous reviewer. Members of the Texas Archeological Society, the Llano Uplift Archeological Society, and the Hill Country Archeological Association heard early versions of this article and offered insightful comments and suggestions. The larger archeological project that included identification of the bois d'arc specimen was made possible by SWCA Environmental Consultants and the Texas Department of Transportation.

\section{REFERENCES CITED}

Alden, H. A.

1995 Hardwoods of North America. General Technical Report FPL-GTR-83. United States Department of Agriculture, Forest Service, Forest Products Laboratory, Madison.

Arnn, J. W.

2007 Transformation and persistence of indigenous cultural identity during the early colonial and late prehistoric periods in Texas. Ph.D. dissertation, Department of Anthropology, University of Kentucky, Lexington.

Asch, N. B. and D. L. Asch

1986 Woodland Period Archeobotany of the Napoleon Hollow Site. In Woodland Period Occupations of the Napoleon Hollow Site in the Lower Illinois Valley, edited by M. D. Wiant and C. R. McGimsey, pp. 427-512. Research Series Vol. 6. Kampsville Archaeological Center, Kampsville.

Ball, J.

2000 The Versatile Osage-Orange. American Forests 106(3):60-62.

Barlow, C.

2000 The Ghosts of Evolution: Nonsensical Fruit, Missing Partners, and Other Ecological Anachronisms. Basic Books, New York.

Bonner, F. T.

2008 Maclura pomifera (Raf. ) Schneid. In Woody Plant Seed Manual, edited by F. T. Bonner and R. P. Karrfalt, pp. 697-699. Handbook 727. United States Department of Agriculture, Forest Service, Washington, D.C.

Bradbury, J.

1817 Travels in the Interior of America in the Years 1809, 1810, and 1811. Sherwood, Neely, and Jones, London. Accessed via Google Books, http://books.google.com. September 9, 2011. 
Brewington, R. L., J. E. Dockall, and H. J. Shafer

1992 Archaeology of the Murphy Branch Site (41MX5): A Middle Caddoan Hamlet in Morris County, Texas. Reports of Investigations No. 1. Center for Environmental Archaeology, Texas A\&M University, College Station.

Burn, M. J. and F. E. Mayle

2008 Palynological Differentiation between Genera of the Moraceae family and Implications for Amazonian Palaeoecology. Review of Palaeobotany and Palynology 149:187-201.

Bush, L. L.

2008 Macrobotanical Remains from the 2005 and 2006 Texas Archeological Society Field Schools at the Gene and Ruth Ann Stallings Site (41LR297). Manuscript on file, Texas Archeological Society, San Antonio.

Burton, J. D.

1990 Maclura pomifera (Raf.) Schneid. Osage-orange (Moraceae - Mulberry family). In Silvics of North America: Volume 2. Hardwoods, edited by R. M. Burns and B. H. Honkala. Agriculture Handbook 654. U.S. Department of Agriculture, Forest Service, Washington, D.C. Available online, http://www.na.fs.fed.us/spfo/pubs/silvics_manual/table_of_contents.htm. Accessed September 10, 2011.

Carey, J. H.

1994 Maclura pomifera. Fire Effects Information System. http://www.fs.fed.us/database/feis. United States Department of Agriculture, Forest Service. Accessed July 28, 2011.

Cheng, Y., X. Jiang, C. Li, and Y. Wang

2011 Pliocene charcoals from Shanxi Province of China and their application to studies of prehistoric wildfires. Science China Earth Sciences 54(4):508-518.

Coder, K. D.

1999 Osage-orange (Maclura pomifera): An American Traveler. Publication FOR99-022. University of Georgia School of Forest Resources Extension, Athens.

Coleman, A. P.

1933 The Pleistocene of the Toronto Region. Ontario Department of Mines Annual Report for 1932, Volume 41, Part VII.

Delanglez, J.

1985 Tonti Letters. In A Jean Delanglez, S.J., Anthology, edited by M. M. Wedel,, pp. 209-238.

Garland Publishing, Inc., New York and London. Originally published 1932 in Mid-America 21(3).

Delevoryas, $\mathrm{T}$.

1964 Two Petrified Angiosperms from the Upper Cretaceous of South Dakota. Journal of Paleontology 38(3):584-586. 
DeMichel, M. (editor)

1713 Journal historique du dernier voyage que feu M. de La Sale fit dans le golfe de Mexique : pour trouver l'embouchure \& le cours de la riviere de Missicipi, nommée à present la riviere de Saint Louis qui traverse la Louisiane : où l'on voit l'histoire tragique de sa mort, \& plusieurs choses curieuses du Nouveau Monde by Henri Joutel. http://www.archive.org/details/cihm_35739. Internet Archive. Accessed September 1, 2011.

Early, A.

2000 Forest Farmsteads: A Millennium of Human Occupation at Winding Stair in the Ouachita Mountains. Research Series 57. Arkansas Archeological Survey, Fayetteville.

Elias, T. S.

1980 The Complete Trees of North America: Field Guide and Natural History. Van Nostrand Reinhold Company, New York.

Flores, D. L. (editor)

1984 Southern Counterpart to Lewis and Clark: The Freeman and Custis Expedition of 1806. University of Oklahoma Press, Norman.

Foster, W. C. (editor)

1998 The La Salle Expedition to Texas: The Journal of Henri Joutel, 1684-1687. Translated by J. S. Warren. Texas State Historical Association, Austin.

Graves, H. S.

1919 The Use of Wood for Fuel. Bulletin No. 753. United States Department of Agriculture, Washington, D.C.

Gremillion, K. J.

1993 Adoption of Old World Crops and Processes of Cultural Change in the Historic Southeast. Southeastern Archaeology 12(1):15-20.

Hamilton, T. M.

1982 Native American Bows. 2nd edition. Special Publications No. 5. Missouri Archaeological Society, Columbia.

Harrisse, $\mathrm{H}$.

1872 Notes pour servir à L'Historie, à la Bibliographie et à la Cartographie de la Nouvelle France et des Pays Adjacents, 1545-1700. Librairie Tross, Paris. Accessed via Google Books, http://books.google.com, September 9, 2011.

Hoadley, R. B.

1990 Identifying Wood: Accurate Results with Simple Tools. The Taunton Press, Newtown, Connecticut. 
Janzen, D. H. and P. S. Martin

1982 Neotropical Anachronisms: The Fruits the Gomphotheres Ate. Science 215(4528):19-27.

Joutel, $\mathrm{H}$.

1684-1687 Relation du Voyage de M. de la Salle dans le nord de l'Amerique Septentrionale en 1684 pour y faire un Etablissement dans la partie qu'il en avoit auparavant découverte. "Copie imparfaite du journal de Joustel qui a été imprime 1684-1687”. Volume 67, No. 1. Archives Nationales Marine, Service Hydrographique, Cartes et Plans. France, Foreign Copying. Manuscript Division, Library of Congress, Washington D.C.

Jurney, D. H.

1995 The Original Distribution of Bois D'Arc, Revised manuscript. http://www.smu.edu/anthro/collections/boisdarc.html. Accessed June 26, 2008. Originally published in the Caddoan Archeology Newsletter V(2), 1994.

Lanner, R. M. and T. R. Van Devender

2000 The Recent History of Pinyon pines in the American Southwest. In Ecology and Biogeography of Pinus, edited by D. M. Richardson, pp. 171-182. Cambridge University Press, Cambridge, United Kingdom.

Margry, P. (editor)

1879 Découverte et établissements des Français dans l'ouest et dans le sud de L'Amérique septentrionale, 16141754 : mémoires et documents inédits. Volume 3. Recherche des bouches du Mississippi et voyages à travers le continent depuis les côtes du Texas jusqu'à Québec (1669-1698).

http://www.archive.org/details/dcouverteett03marg. Internet Archive. Accessed September $1,2011$.

Martínez-Cabrera, H. I., S. R. S. Cevallos-Ferriz, and I. Poole

2006 Fossil woods from early Miocene sediments of the El Cien Formation, Baja California Sur, Mexico. Review of Palaeobotany and Palynology 138:141-163.

Moerman, D.

1998 Native American Ethnobotany. Timber Press, Portland.

Panshin, A. J. and C. de Zeeuw

1980 Textbook of Wood Technology: Structure, Identification, Properties, and Uses of the Commercial Woods of the United States and Canada. Fourth edition. McGraw-Hill Book Company, New York.

Peattie, D. C.

2007 A Natural History of North American Trees. Houghton Mifflin Company, Boston. Originally published 1953 in two volumes.

Perttula, T. K., L. L. Bush, L. Schniebs, T. Middlebrook, and P. S. Marceaux

2010 An Early Historic Caddo Farmstead at the Henry M. Site (41NA60) in Nacogdoches, County, Texas. Stephen F. Austin State University Press, Nacogdoches, Texas. 
Powell, A. M.

1998 Trees and Shrubs of the Trans-Pecos and Adjacent Areas. University of Texas Press, Austin.

Roberts, T.

2011 Tracing the Comanche Trail across the Trans Pecos-Big Bend Region of Texas From Horsehead Crossing on the Pecos to the Rio Grande. Paper presented at the Annual Meeting of the County Historical Commissions from the Mountain-Pecos Region, Marathon, Texas, January 22, 2011.

Roemer, F.

2011 Roemer's Texas, with particular reference to German immigration and the physical appearance of the country. Translated by Oswald Mueller. Mockingbird Books. Retrieved from http://books.google.com/books/about/Roemer_s_Texas.html. Originally published 1935.

Schambach, F. F.

1995 A Probable Spiroan Entrepot in the Red River Valley in Northeast Texas. Caddoan Archeology Newsletter 6(1):9-25.

Shackelton, C. M. and F. Prins

1992 Charcoal analysis and the "Principle of Least Effort": A Conceptual Model. Journal of Archaeological Science 19:631-638.

Simpson, Benny J.

1999 A Field Guide to Texas Trees. Lone Star Books, Laham, Massachusetts.

Smith, J. L. and J. V. Perino

1981 Osage Orange (Maclura pomifera): History and Economic Uses. Economic Botany 35(1):24-41.

Stahle, D. W., E. R. Cook, M. K. Cleaveland, M. D. Therrell, D. M. Meko, H. D. Grissino-Mayer, E. Watson, and B. H. Luckman

2000 Tree-ring Data Document $16^{\text {th }}$ Century Megadrought Over North America. Eos 81(12):121132.

Starr, F., K. Starr, and L. Loope

2003 Maclura pomifera (Osage orange), Moraceae. http://www.hear.org/starr/hiplants/reports/pdf/maclura_pomifera.pdf. United States Geological Survey, Biological Resources Division, Haleakala Field Station, Maui, Hawai'i. Accessed September 8, 2011.

Terasmae, J.

1960 A Palynological Study of Pleistocene Interglacial Beds at Toronto, Ontario. Geological Survey of Canada Bulletin 56 (Part II):23-41. 
TEX-LL (Flora of Texas Database)

2007 Flora of Texas Database, Plant Resources Center, University of Texas at Austin. http://www.biosci.utexas.edu/prc/Tex.html. Accessed September 9, 2011.

Turner, B. L., H. Nichols, G. Denny, and O. Doron

2003 Atlas of the Vascular Plants of Texas, Volume 1:Dicots. Botanical Research Institute of Texas Press, Fort Worth.

Turner, M. W.

2009 Remarkable Plants of Texas: Uncommon Accounts of Our Common Natives. University of Texas Press, Austin.

Wade, M. F.

2003 The Native Americans of the Texas Edwards Plateau, 1582-1799. University of Texas Press, Austin.

Webb, C. H. and R. R. McKinney

1963 An Unusual Pottery Vessel from the Mounds Plantation Site, Caddo Parish, Louisiana. Arkansas Archaeologist 4(5):1-9.

1975 Mounds Plantation (16CD12), Caddo Parish, Louisiana. Louisiana Archaeology 2:39-127.

Weniger, D.

1996 Catalpa (Catalpa bignoniodes, Bignoniaceae) and Bois d'Arc (Maclura pomifera, Moraceae) in Early Texas Records. Sida 17:231-242.

Westbrook, R. F.

1973 State-Wide Service Test of Fence Posts: Twenty-Year Progress Report. Publication 110. Texas Forest Service, Forest Products Department, Texas A\&M University, Lufkin.

Whipple, A. W.

1856 Extracts from the [Preliminary] Report of Lieutenant A. W. Whipple, Corps of Topographical Engineers, upon the Route near the Thirty-Fifth Parallel, with an Explanatory Note by Captain A. A. Humphreys, Corps of Topographical Engineers. In Reports of Explorations and Surveys, to ascertain the most practicable and economical route for a railroad from the Mississippi River to the Pacific Ocean, made under the direction of the Secretary of War, in 1853-4. Volume III. Washington, Government Printing Office. Accessed online http://cprr.org/Museum/Pacific_RR_Surveys/, September 9, 2011.

Wilson, O. W.

1966 Pioneer Surveyor, Frontier Lawyer: The Personal Narrative of O. W. Williams, 1877-1902. Edited by S. D. Myres. Texas Western College Press, El Paso.

Woodcock, D. W.

1989 Significance of Ring Porosity in Analysis of a Sangamon Flora. Palaeogeography, Palaeoclimatology, Palaeoecology 73:197-204. 
Woodhouse, C. A., D. M. Meko, G. M. MacDonald, D. W. Stahle, and E. R. Cook

2010 A 1,200-year Perspective of $21^{\text {st }}$ Century Drought in Southwestern North America.

Proceedings of the National Academy of Sciences of the United States of America 107(50):2128321288. 